\title{
Stand density management and blue carbon stock of monospecific mangrove plantation in Bohol, Philippines
}

\author{
Dixon T. Gevaña*, Leni D. Camacho and \\ Sofronio C. Camacho
}

Gevaña, D.T., Camacho, L.D., Camacho, S.C. 2017. Stand density management and blue carbon stock of monospecific mangrove plantation in Bohol, Philippines. Forestry Studies | Metsanduslikud Uurimused 66, 75-83. ISSN 1406-9954. Journal homepage: http://mi.emu.ee/forestry.studies

\begin{abstract}
Blue carbon pertains to carbon stock that is stored by marine ecosystems including mangrove forest. Density and blue carbon stock assessment was conducted covering mature Rhizophora stylosa Griff. plantations in Bohol, Philippines. Three stand types were assessed: thinned mature stand $\left(0.34\right.$ tree $\mathrm{m}^{-2}$ at 55 years old; $35 \mathrm{ha}$ ); non-thinned mature stand (1.2 tree $\mathrm{m}^{-2}$ at 55 years old; $20 \mathrm{ha}$ ) and young stand ( 2.6 tree $\mathrm{m}^{-2}$ at 20 years old; $150 \mathrm{ha}$ ). These plantations were initially established with a plant spacing of $0.5 \mathrm{~m} \times 0.5 \mathrm{~m}$. Non-destructive plot sampling technique was used to account biomass and carbon stocks of trees and sediments. Five (5) sample plots measuring $200 \mathrm{~m}^{2}$ were allocated for each stand type. Results showed that the total carbon stock of plantations amassed to $64.5 \mathrm{ktC}$ or $236.6 \mathrm{ktCO}_{2} \mathrm{e}$. More than half (at least $54 \%$ ) of this stock is imbedded in sediment. Individual accounts showed that carbon stock was largest in non-thinned stand with $435.2 \mathrm{tC} \mathrm{ha}^{-1}$, followed by thinned stand (408.5 $\left.\mathrm{tC} \mathrm{ha} \mathrm{h}^{-1}\right)$ and young stand $\left(276.8 \mathrm{tC} \mathrm{ha}^{-1}\right)$. There was no significant difference between thinned and non-thinned mature stands carbon stocks. Such finding suggested the potential of having thinning intervention. Following the self-thinning rule of 1.1 to 1.3 tree $\mathrm{m}^{-2}$, the local community can harvest as much as 423 trees ha-1 $\mathrm{yr}^{-1}$ for 35 years starting at the plantation age of 20 years. Further, the additional carbon stock between the ages 20 to 55 years could reach about $580 \mathrm{tCO}_{2} \mathrm{e} \mathrm{ha}^{-1}$ with an economic value of USD 2,962 ha-1. With this potential benefits, it is recommended that Banacon Island should pursue a carbon offset project for its plantations.
\end{abstract}

Key words: carbon stock, climate change, mangrove, stand, thinning.

Authors' address: College of Forestry and Natural Resources, University of the Philippines, Los Baños, Laguna 4031, Philippines; *e-mail: dtgevana@up.edu.ph

\section{Introduction}

Mangroves are among the world's most productive ecosystems. They enrich coastal waters, yield commercial forest products, protect coastlines, and support coastal fisheries. They have unique characteristic by being true ecotones of land and ocean. The term mangrove denotes two different concepts according to Lugo \& Snedaker (1974) and Alongi (2010). First, it refers to a group of salt-tolerant plants belonging to nine orders, 20 families, 27 genera, and roughly 70 species. These plants have natural capacity to cope with changes in water and sediment salinity. Second, it refers to complex plant communities that fringe tropical and subtropical $\left(32^{\circ} \mathrm{N}\right.$ to $\left.32^{\circ} \mathrm{S}\right)$ shores and delimited by major ocean currents and temperature (Saenger, 2002). Mangroves 
are also well adapted to deal with natural stressors such as high temperature, anaerobic sediments, and extreme tides.

Mangrove forests are highly productive carbon sinks. They absorb and sequester vast amount of carbon dioxide from the atmosphere. Their carbon stock capacity reaches as much as $1,023 \mathrm{tC} \mathrm{ha}^{-1}$, an estimate that is three times larger than those of other tropical forest ecosystems (Donato $e t$ al., 2011). Bulk of this stock is contained in their sediment or peat.

Despite the vital role in climate change mitigation, mangroves are in danger of complete denudation (Kathiresan \& Bingham, 2001; Richards \& Friess, 2016). In many regions, they are being converted to aquaculture ponds, sewage disposal sites, human settlement areas and industrial ports (Saenger, 2002; Garcia et al., 2014). Globally they have dwindled to 15.2 million ha, and continuously shedding off at a rate of 102,000 ha $\mathrm{yr}^{-1}(\mathrm{FAO}, 2007)$. The Philippines shared a similar downtrend where $70 \%$ of its original cover had been lost over the past century. Its mangroves are now accounted to 153,577 ha (DENR, 2013). Such loss means forgone opportunities for more carbon stocks. As a response, the Philippine government has passed a number policies to prohibit commercial cutting of mangrove trees. One of these is the Republic Act 7171 (Act of Incorporating Certain Sections of the National Revenue Code) which stipulates a no cut policy for all mangrove stands may it be natural or plantation forest.

Seeing the dismal trend of mangrove deforestation, efforts to rehabilitate degraded mangroves through reforestation became more visible over the past three decades (Puhlin et al., 2017). Mangrove rehabilitation projects were seen in many community-based coastal resource management programs of the government and local communities. Among the government's largest mangrove rehabilitation efforts was the National Greening Program which started in 2011 (Adornado, 2016). This program has tapped local communities and local government units to implement mangrove planting which has now re-vegetated 45,000 ha of denuded coasts. IUCN (2012) noted that it is just a matter of time that such efforts will be soon rewarded. With the recent inclusion of mangroves (as blue carbon ecosystem) in the United Nations Conference on Climate Change (UNFCCC) negotiations on Reducing Emissions from Deforestation and Forest Degradation (REDD), more projects on mangrove carbon financing and trading are expected to come over the next few years.

This study sought to provide some sustainability considerations for communitybased mangrove plantation management as far as stand density management vis-àvis carbon sequestration potentials is concern. Further, it was aimed to discuss how carbon stock and subsistent utilization of wood can be harmonize in order to achieve the twin goal of ecological and economic development. By taking Rhizophora stylosa Griff. plantations in Banacon Island in Bohol, Philippines as its case, the potential effect of thinning and non-thinning on aboveground and sediment carbon stock production was assessed.

\section{Material and Methods}

\section{Duration and study site}

Field data collection took place from June 2012 to March 2014. Sample sites were established along the eastern and western portion of Bancon Island, Philippines covering $R$. stylosa plantations with ages ranging from 20 to 55 years old (Figure 1). The island is located at the northwestern part of Bohol Province covering two small communities, Banacon and Jagoliao, which are home to at least 300 households. It has an area of about 660 ha that lies along $10^{\circ}$ $03^{\prime} 30^{\prime \prime}$ to $10^{\circ} 15^{\prime} 30^{\prime \prime} \mathrm{N}$ and $124^{\circ} 03^{\prime} 30^{\prime \prime}$ to $124^{\circ} 14^{\prime} 30^{\prime \prime} \mathrm{E}$; and forms part the ecodiverse protected marine sanctuary of Danajon Double Barrier Reef (Pichon, 1977). The climate of the island belongs to Type 


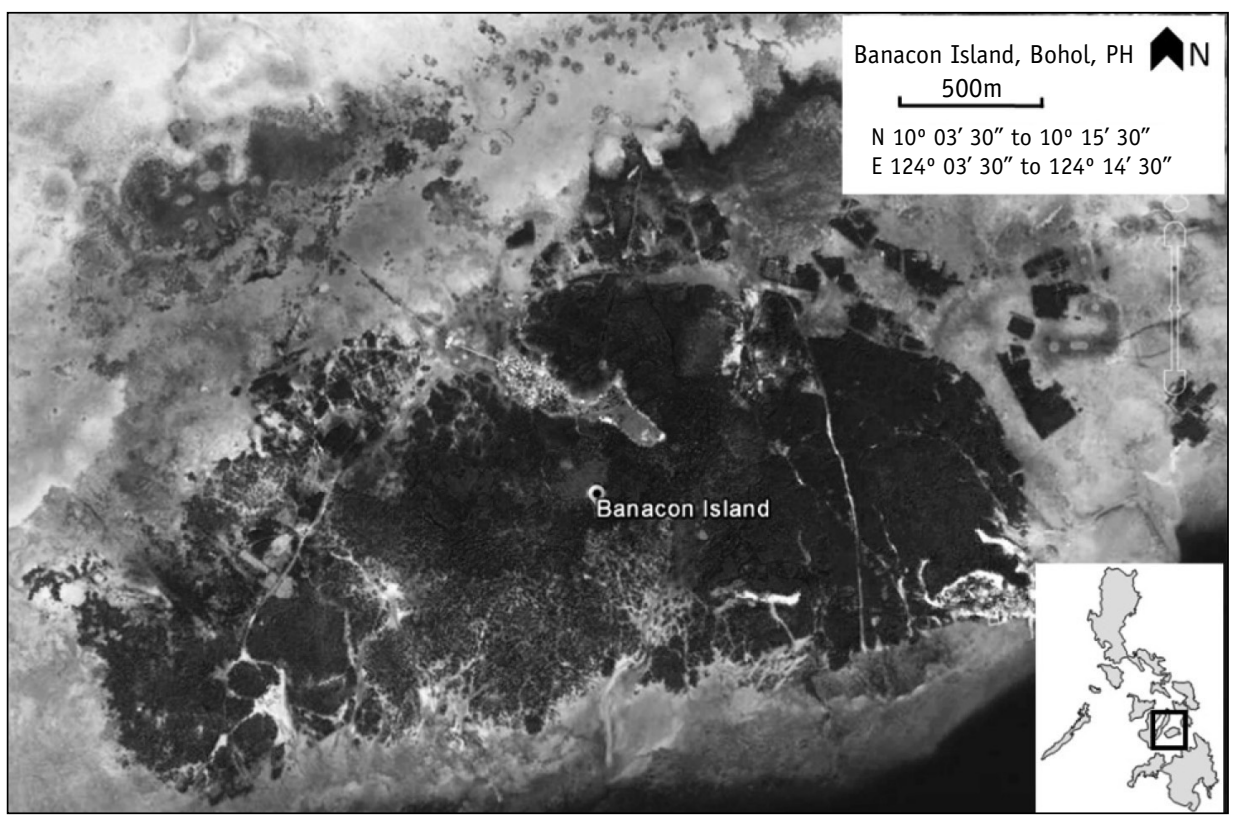

Figure 1. Location map of Banacon Island, Bohol, Philippines (Google Earth ver. 7.1).

IV of the Corona Classification which depicts 'no distinct dry season'. Its sediment is typically sandy to mud with $\mathrm{pH}$ ranging from 7.65 to 8.59 .

\section{Sampling site}

Prior to biomass and carbon stock assessment, an ocular survey of mangrove plantations was performed to categorize sampling sites. Two major plantation types were then identified based on age groups: mature (50 to 55 years old) and young (20 years old). The information about the plantation ages was provided by the local community who implemented the mangrove planting. Mature plantations were further classified into two types based on their density and stand management condition: a) thinned; and b) non-thinned. All these plantations were established using $0.5 \mathrm{~m} \times$ $0.5 \mathrm{~m}$ spacing. They are in proximity with one another as they are situated along a common stretches of shallow sandbars. Figure 2 shows the typical view of mature and young $R$. stylosa plantations in Banacon Island.
Stands with thinning is a result of occasional and selective cutting of mature trees. This type of management was described as irregular and unplanned since the local residents harvest trees (in any amount) depending on their needs. Commonly, big diameter trees $(>5 \mathrm{~cm})$ trees are harvested for their poles (for building house, seaweed posting and boat construction) while small diameter saplings $(<5 \mathrm{~cm})$ are for house fencing and fuelwood. Thinning locations are usually along stand peripheries and trails for more convenient extraction and hauling of tree. By estimate, about 1,400 trees are being harvested annually from thinned mature stands, which suggests about 40 trees $\mathrm{ha}^{-1} \mathrm{yr}^{-1}$ harvesting rate. Most of the thinned stands are situated near the settlement area at the eastern portion of the island.

Non-thinned mature stands are those areas where no cutting was done, including the young stands. With still intact and lush vegetation, these stands were identified as potential ecotourism spot by the local community. 


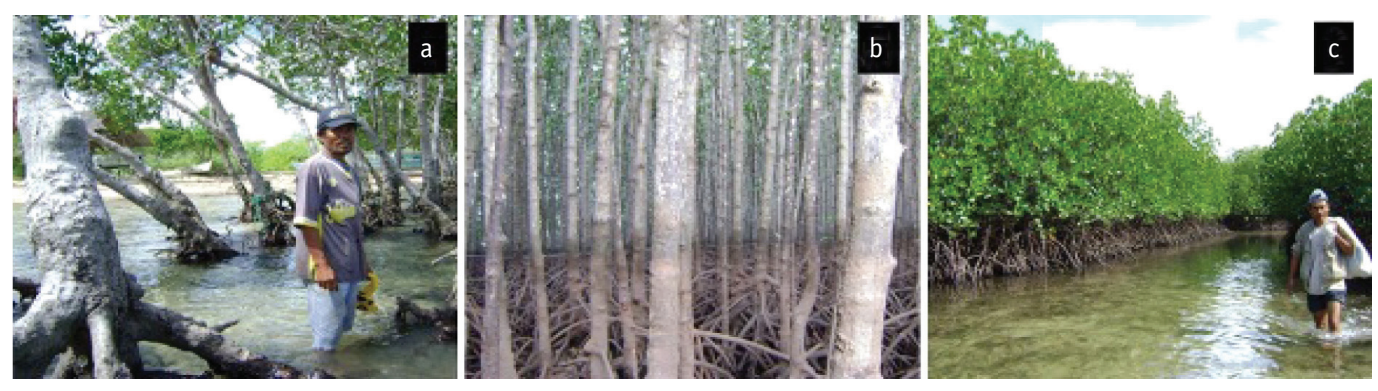

Figure 2. Tile view of mature and young Rhizophora stylosa Griff. plantations in Banacon Island where: a) thinned mature stand; b) non-thinned mature stands; c) young stands (also non-thinned).

\section{Tree carbon stock sampling}

Sampling followed the standard plot technique developed by Hairiah et al. (2001). Plots have a dimension of $5 \mathrm{~m} \times 40 \mathrm{~m}$ that is specifically designed for carbon stock accounting of natural forests, plantations and agroforestry farms. A total of five (5) plots were established for each stand type (mature: thinned and non-thinned; and young). Distance between the sample plots was at least 40 meters capturing both the landward and seaward exposure of the stands. All trees measuring $3.5 \mathrm{~cm}$ diameter inside the plot were accounted in terms of their local name, species, diameter $(\mathrm{cm})$ and total height $(\mathrm{m})$. This minimum diameter limit is required for the allometric equation used. A minimum distance of 30 $\mathrm{m}$ between plots was observed since plantations and natural stands are both contiguous and homogenous in distribution.

To calculate total tree biomass (stem, crown, branches and roots), the allometric equation below was used. This equation has an $R^{2}$ of 0.96 , specifically designed for $R$. stylosa trees of Banacon Island (Gevana \& Im, 2016). Tree carbon stock (kg) was computed by multiplying tree biomass with the average wood carbon content of R. stylosa i.e. $45.4 \%$.

$$
y=0.178 \times D^{2.586}
$$

Where: $y$ is the total tree biomass $(\mathrm{kg})$

$\mathrm{D}$ is the stem diameter $(\mathrm{cm})$
Sampling requirement was determined by following the sampling guidelines developed by the United Nations Framework Convention on Climate Change (UNFCCC) for accounting carbon stocks in Clean Development Mechanism (CDM) projects (i.e AR-AM0001, AM0005, and AM0006) (Pearson et al., 2005). A total of fifteen plots were established to collect the necessary biomass information from the mangrove plantations.

\section{Sediment carbon stock}

Sediment bulk density was determined by choosing an undisturbed spot inside plot, and carefully driving core samplers into the organic layer or mud within 100 $\mathrm{cm}$ depth. Sediment depth was determined using temper bar, digging the mud to observe the organic matter thickness. The core sampler has a dimension of $5 \mathrm{~cm}$ height and $5 \mathrm{~cm}$ circumference. Four core samples were obtained from each plot and later ovendried (at $105{ }^{\circ} \mathrm{C}$ for two days). About $200 \mathrm{~g}$ of sediment sample was also collected at the same sampling spots, and was later sent to laboratory for carbon content analysis using Walkey-Black Method. Soil carbon stock was then computed using the following equations:

Bulk Density $\left(\mathrm{g} \mathrm{cm}^{-3}\right)=$ Dry weight of core $(\mathrm{g}) /$ volume of cylinder $\left(\mathrm{cm}^{3}\right)$

Sediment mass $\left(\mathrm{t} \mathrm{ha}^{-1}\right)=$ bulk density $\left(\mathrm{g} \mathrm{cm}^{-3}\right) \times$ depth $(\mathrm{cm}) \times 100$ 
Sediment carbon stock $\left(\mathrm{tC} \mathrm{ha}^{-1}\right)=$ sediment mass $\times(\mathrm{C}(\%) / 100)$

\section{Total carbon stock}

Total carbon stock ( $\mathrm{tC} \mathrm{ha-1)}$ was computed by getting the sum of tree and sediment carbon stocks. Litter at the forest floor was not included in the assessment since this component is usually absent as they are displace and flush away by daily tidal changes.

\section{Results and Discussion}

\section{Biometric description}

Density of non-thinned stands was estimated as 11,580 trees ha $^{-1}$ while thinned stands contains 3,420 trees ha ${ }^{-1}$. According to the local residents, the relatively lesser stocked condition of thinned stands can be largely attributed to subsistent harvesting to meet local needs for fuelwood and pole (needed for house construction and seaweed farming) that is estimated to about 1,400 trees per year. Harvesting is more prominent on stands that are near the settlement area for more convenient hauling. Other likely factors that likely contributed to decrease in density are self-thinning ${ }^{1}$, occurrence of plant diseases, wave surges and exposure to extreme temperature. In terms of young stands, density was estimated to 26,400 trees ha ${ }^{-1}$.

In view of diameter, larger mean value was noted for thinned stands with $12.1 \pm$ $0.5 \mathrm{~cm}$. This can be attributed to its relatively lesser stocked condition which have likely favored tree diameter growth. Normally, the wider canopy opening favors stem and crown lateral growth because lesser competition among trees over sediment nourishment and sunlight (Chan, 1996; Saenger, 2002). On the other hand,

1 Self-thinning is the natural stand process whereby numbers of trees (usually even-aged) per unit area decrease as average tree size increases over time (Oliver \& Larson, 1996). trees of non-thinned stand was estimated to $7.3 \pm 0.1 \mathrm{~cm}$, while those in young stands was around $4.8 \mathrm{~cm}$.

Table 1. Summary of stand density, diameter (D) and height $(\mathrm{H})$ values of mature and young Rhizophora stylosa Griff. stands.

\begin{tabular}{|c|c|c|c|}
\hline Plot & $\begin{array}{c}\text { Density } \\
(\text { trees ha-1) }\end{array}$ & $\begin{array}{l}\text { Ave. D } \\
(\mathrm{cm})\end{array}$ & $\begin{array}{l}\text { Ave. } \mathrm{H} \\
(\mathrm{m})\end{array}$ \\
\hline \multicolumn{4}{|c|}{$\begin{array}{l}\text { Thinned stand } \\
\text { Location: N } 10^{\circ} 11^{\prime} 52^{\prime \prime} ; \text { E } 124^{\circ} 10^{\prime} 52^{\prime \prime} \\
\text { Stand Age (yr): } 50-55 ; \\
\text { Estimated area (ha): } 35\end{array}$} \\
\hline Plot 1 & 2250 & $12.8 \pm 0.3$ & 10.6 \\
\hline Plot 2 & 2450 & $11.6 \pm 0.5$ & 10.6 \\
\hline Plot 3 & 2850 & $12.2 \pm 0.4$ & 9.5 \\
\hline Plot 4 & 3050 & $13.7 \pm 0.4$ & 6.3 \\
\hline Plot 5 & 6500 & $10.42 \pm 0.2$ & 6.5 \\
\hline Ave. & 3420 & $12.1 \pm 0.5$ & $8.7 \pm 1.0$ \\
\hline \multicolumn{4}{|c|}{$\begin{array}{l}\text { Non-thinned mature sta } \\
\text { Location: N } 10^{\circ} 11^{\prime} 58^{\prime \prime} ; \\
\text { Stand age (yr): } 50-55 ; \\
\text { Estimated area (ha): } 20\end{array}$} \\
\hline Plot 1 & 10900 & $7.6 \pm 2.1$ & 12.1 \\
\hline Plot 2 & 12000 & $7.1 \pm 0.1$ & 13.0 \\
\hline Plot 3 & 13150 & $7.1 \pm 0.1$ & 12.5 \\
\hline Plot 4 & 11150 & $7.2 \pm 0.1$ & 13.0 \\
\hline Plot 5 & 10700 & $7.4 \pm 0.2$ & 13.0 \\
\hline Ave. & 11580 & $7.3 \pm 0.1$ & $12.7 \pm 0.2$ \\
\hline \multicolumn{4}{|c|}{$\begin{array}{l}\text { Young stand } \\
\text { Location: N } 10^{\circ} 12^{\prime} 28^{\prime \prime} ; \\
\text { Stand Age (yr): } 20 ; \\
\text { Estimated area (ha): } 150\end{array}$} \\
\hline Plot 1 & 26800 & $4.8 \pm 0.1$ & 4.1 \\
\hline Plot 2 & 33200 & $4.6 \pm 0.1$ & 4.1 \\
\hline Plot 3 & 20100 & $4.9 \pm 0.1$ & 4.1 \\
\hline Plot 4 & 24300 & $4.8 \pm 0.1$ & 4.1 \\
\hline Plot 5 & 27600 & $4.8 \pm 0.1$ & 4.1 \\
\hline Ave. & 26400 & $4.8 \pm 0.0$ & $4.1 \pm 0.0$ \\
\hline
\end{tabular}

Taller height was observed in non-thinned stands with $12.7 \pm 0.2 \mathrm{~m}$. Typically, closer spacing can spur height growth as trees compete for crown dominance and sunlight (Oliver \& Larson, 1996). Conversely, trees in thinned stands was relatively smaller with $8.7 \pm 1.0 \mathrm{~m}$ which likely reflective of lesser crown competition. In terms of the young stands, trees have height of about $4.1 \mathrm{~m}$. 


\section{Tree Biomass and carbon stocks}

Summary of carbon stocks at different levels or pools (tree, sediment and total) across stands is presented in Table 2 and Figure 3. Slight but significantly larger biomass (5 t $\left.\mathrm{ha}^{-1}\right)$ and carbon stock $\left(2.1 \mathrm{tC} \mathrm{ha}^{-1}\right)$ were observed in thinned stand over non-thinned stands (Table 3). By estimate their biomass and carbon stocks were $406.6 \pm 53.0 \mathrm{t} \mathrm{ha}^{-1}$ and $184.6 \pm 24.1$. $\mathrm{tC} \mathrm{ha-1}$, respectively for the former; as compared to $401.9 \pm 12.1 \mathrm{t}$ $\mathrm{ha}^{-1}$ and $182.5 \pm 5.5 \mathrm{tC} \mathrm{ha}^{-1}$ each for the latter. This indicates that harvesting of trees can somehow help improve tree carbon stock production of $R$. stylosa plantations at their mature age. On the other hand, tree biomass and carbon stock of young stands were $363.5 \pm 23.3 \mathrm{t} \mathrm{ha}^{-1}$ and $166.7 \pm 10.7 \mathrm{tC}$ ha $^{-1}$, respectively.

Values obtained from this study are comparable with the estimates reported abroad. For instance, Putz \& Chan (1986) has estimated about 135 to $230 \mathrm{tC} \mathrm{ha}^{-1}$ for non-thinned mature ( $>80$ years old) $R h i-$ zophora stands in Matang Mangrove Forest in Malaysia. In Ryukyu Island, Japan, Nagasuka (1979) reported about $92.6 \mathrm{tC} \mathrm{ha}^{-1}$ for mature Rhizophora apiculata Blume stand with a density of 9,600 trees ha ${ }^{-1}$. Lastly, around $200 \mathrm{tC}$ ha $^{-1}$ was observed for old growth $R$. apiculata stand in Ranong, Thailand with a stand density of 2,346 trees ha ${ }^{-1}$ by Tamai et al. (1986).

\section{Sediment carbon stock}

Carbon stock at sediment pool ranged from 223.9 tC ha-1 to $252.7 \mathrm{tC} \mathrm{ha}^{-1}$ (Table 2). Between the mature stands, larger estimate was noted for non-thinned plantations with a mean difference of as much as $28.8 \mathrm{tC} \mathrm{ha}^{-1}$ (Table 3 ). This stand has thicker sediment layer with about $1.2 \mathrm{~m}$ as compared to thinned stand with only about $0.7 \mathrm{~m}$. Such difference is reflective of the denser vegetation of the former which is likely to produce more organic matter through litterfall, and denser root systems that traps floating allochthonous materials. However, such difference was not found significantly different between the two stands which suggests that leaving the plantations unthinned or unharvested may not guarantee larger sediment carbon stock. In terms of young stand, carbon stock was accounted to110.1 $\mathrm{tC}^{\mathrm{C}} \mathrm{ha}^{-1}$ with an organic matter depth of $0.75 \mathrm{~m}$.

Reports abroad for Rhizophora stands also showed comparable values. For instance, Matsui (1998) measured 182 to $381 \mathrm{tC}^{\mathrm{ha}} \mathrm{h}^{-1}$ for Hinchinbrook mangroves, Australia. Extremely larger estimate was reported by Donato et al. (2011) for mangroves along the Indo-Pacific region with at least $1000 \mathrm{tC} \mathrm{ha}^{-1}$, hence indicating the important role of sediments in carbon storage.

\section{Total carbon stocks}

Total carbon stock of thinned and nonthinned mature stands were $408.5 \pm 30.0 \mathrm{tC}$ $\mathrm{ha}^{-1}$ and $435.2 \pm 29.1 \mathrm{tC} \mathrm{ha}^{-1}$, respectively. More than half (at least 54\%) of their values are imbedded in the sediment layer. Result of difference tests revealed that there is no significant advantage in non-thinning the mature plantation stands having a mean difference of only $26.7 \mathrm{tC} \mathrm{ha-1}$ a (Table 3 ). This also suggests that thinning could be a favorable option since it can produce a comparable amount of carbon stock if unthinned.

In terms of young stands, total carbon stock was estimated to $276.8 \pm 11.6 \mathrm{tC} \mathrm{ha}^{-1}$. Similar with mature stands, bulk $(60 \%)$ of the carbon stock is stored in sediment.

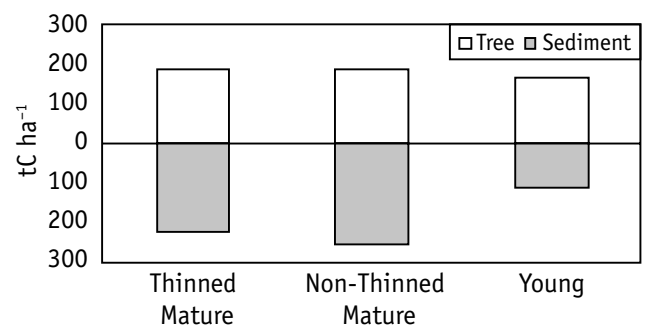

Figure 3. Tree and sediment contribution to carbon stock of mature and young Rhizophora stylosa Griff. stands of Banacon stands in Banacon Island, Philippines. 
Table 2. Summary of biomass and carbon stock of mature and young Rhizophora stylosa Griff. stands in Banacon Island, Philippines.

\begin{tabular}{|c|c|c|c|c|c|c|}
\hline \multirow[t]{2}{*}{ Site } & \multicolumn{2}{|c|}{ Tree } & \multicolumn{2}{|c|}{ Sediment } & \multirow{2}{*}{$\begin{array}{c}\text { Total carbon } \\
\text { stock } \\
\left(\mathrm{tC} \mathrm{ha}^{-1}\right)\end{array}$} & \multirow{2}{*}{$\begin{array}{l}\mathrm{CO}_{2} \text { Equivalent } \\
\mathrm{tCO}_{2} \mathrm{e} \mathrm{ha}^{-1}\end{array}$} \\
\hline & $\begin{array}{c}\text { Biomass } \\
\left(\mathrm{t} \mathrm{ha}^{-1}\right)\end{array}$ & $\begin{array}{c}\text { Carbon stock } \\
\left(\mathrm{tC} \mathrm{ha}^{-1}\right)\end{array}$ & $\begin{array}{c}\text { Carbon stock } \\
\left(\mathrm{tC} \mathrm{ha}^{-1}\right)\end{array}$ & $\begin{array}{l}\text { OM Depth } \\
\text { (cm) }\end{array}$ & & \\
\hline \multicolumn{7}{|c|}{ A. Thinned mature stand } \\
\hline Plot 1 & 305.6 & 138.7 & 204.4 & 70 & 343.1 & 1258.0 \\
\hline Plot 2 & 291.9 & 132.5 & 260.9 & 70 & 393.4 & 1442.5 \\
\hline Plot 3 & 371.1 & 168.5 & 218.1 & 70 & 386.6 & 1417.5 \\
\hline Plot 4 & 526.3 & 238.9 & 283.3 & 70 & 522.2 & 1914.8 \\
\hline Plot 5 & 538 & 244.2 & 153.0 & 70 & 397.2 & 1456.4 \\
\hline Average & 406.6 & 184.6 & 223.9 & 70 & 408.5 & 1497.8 \\
\hline SE & 53.0 & 24.1 & 22.7 & 0 & 30.0 & 246.2 \\
\hline \multicolumn{7}{|c|}{ D. Non-thinned mature stand } \\
\hline Plot 1 & 433.4 & 196.7 & 265.8 & 120 & 462.5 & 1695.8 \\
\hline Plot 2 & 375.8 & 170.6 & 248.5 & 120 & 419.1 & 1536.7 \\
\hline Plot 3 & 425.5 & 193.2 & 322.0 & 120 & 515.2 & 1889.1 \\
\hline Plot 4 & 375.7 & 170.6 & 167.3 & 120 & 337.9 & 1239.0 \\
\hline Plot 5 & 399.3 & 181.3 & 259.9 & 120 & 441.2 & 1617.7 \\
\hline Average & 401.9 & 182.5 & 252.7 & 120 & 435.2 & 1595.7 \\
\hline SE & 12.1 & 5.5 & 24.8 & 0 & 29.1 & 238.4 \\
\hline \multicolumn{7}{|c|}{ C. Young Stand } \\
\hline Plot 1 & 356.7 & 163.6 & 97.7 & 75.0 & 261.3 & 958.1 \\
\hline Plot 2 & 439.3 & 201.4 & 116.2 & 75.0 & 317.6 & 1164.5 \\
\hline Plot 3 & 298.1 & 136.7 & 117.6 & 75.0 & 254.3 & 932.4 \\
\hline Plot 4 & 341.7 & 156.7 & 107.2 & 75.0 & 263.9 & 967.6 \\
\hline Plot 5 & 381.9 & 175.2 & 111.9 & 75.0 & 287.1 & 1052.7 \\
\hline Average & 363.5 & 166.7 & 110.1 & 75.0 & 276.8 & 1014.9 \\
\hline SE & 23.3 & 10.7 & 3.6 & 0.0 & 11.6 & 95.0 \\
\hline
\end{tabular}

Table 3. Test of difference between thinned and non-thinned mature Rhizophora stylosa Griff. stands in Banacon Island, Philippines.

\begin{tabular}{|c|c|c|c|c|}
\hline Assumption & $t$ & $f$ & $\begin{array}{l}\text { Mean Difference } \\
\left(\mathrm{tC} \mathrm{ha}^{-1}\right)\end{array}$ & $p$ \\
\hline $\begin{array}{l}\text { Tree C stock } \\
\text { Equal variances assumed } \\
\text { Equal variances not assumed }\end{array}$ & $\begin{array}{l}0.08 \\
0.08\end{array}$ & 19.65 & 2.08 & 0.02 \\
\hline $\begin{array}{l}\text { Sediment C stock } \\
\text { Equal variances assumed } \\
\text { Equal variances not assumed }\end{array}$ & $\begin{array}{l}0.85 \\
0.85\end{array}$ & 0.02 & 28.76 & 0.90 \\
\hline $\begin{array}{l}\text { Total C stock } \\
\text { Equal variances assumed } \\
\text { Equal variances not assumed }\end{array}$ & $\begin{array}{l}0.64 \\
0.64 \\
\end{array}$ & 0.00 & 26.68 & 1.00 \\
\hline
\end{tabular}

\section{Implications to Stand Density Management}

Figure 4 provides an essential basis for determining the likely stand density management approach for better tree carbon stock production. In general, the self-thinning line rest at 1.1 to 1.3 tree $\mathrm{m}^{-2}$ on the maxi- mum. This suggests that stand density beyond this point will not yield much additional carbon stock because trees are already onwards the climax stage. This also suggests that tree mortality is likely to occur for stands with density that is beyond this level. The observed negative thinning 
line i.e $k=-0.88$ conformed well to the studies conducted by Yoda et al. (1963) for -3/2 self-thinning rule, Westoby (1984) and Weller (1987) for various forest tree species $(k=-1.5)$, and Deshar et al. (2012) for mangroves $(k=-1.1)$.

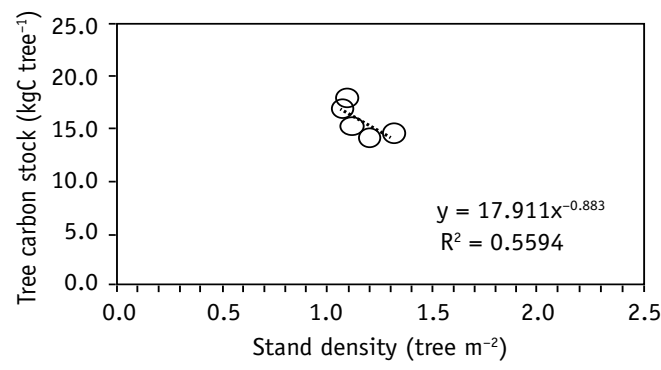

Figure 4. Self-thinning line based on stand density (tree $\mathrm{m}^{-2}$ ) and mean individual tree carbon stock $\left(\mathrm{kgC} \mathrm{m}^{-2}\right)$ of non-thinned mature Rhizophora stylosa Griff. plantation in Banacon Island, Philippines.

Following the self-thinning rule, it is expected that the plantation density will naturally decline from about 26,400 trees $\mathrm{ha}^{-1}$ (at the age of 20 years) to around 11,500 trees ha-1 (at the age of 55 years). Such inevitable decrease should therefore be considered as an opportunity for the local community to intentionally harvest wood rather than losing them because of natural thinning. If thinning management will be done between 20 to 55 years, the local community can get as much as 14,800 trees $\mathrm{ha}^{-1}$. Thinning intensity could be set at the maximum of 423 trees ha-1 $\mathrm{yr}^{-1}$ or 1.1 to 1.3 tree $\mathrm{m}^{-2}$ to ensure good carbon stock.

Pursuing a carbon offset project could further provide economic benefits for maintaining the plantations well-stocked. By estimate, young stand (150 ha) has the capacity to store as much as $152.2 \mathrm{ktCO}_{2} \mathrm{e}$. This has a potential economic value of USD $5,176 \mathrm{ha}^{-1}$ which is based on the current average voluntary carbon market price of USD $5.1 \mathrm{tCO}_{2} \mathrm{e}$ for forest and land use activities (Ecosystem Marketplace, 2017). If these stands will be thinned up to 35 years, following the self-thinning rule of 1.1 to
1.3 tree $\mathrm{m}^{-2}$, an additional $580 \mathrm{tCO}_{2} \mathrm{e} \mathrm{ha}^{-1}$ or USD 2,962 ha-1 can be produced.

In view of mature stands, the potential carbon of thinned plantation (35 ha) is around $52.4 \mathrm{ktCO}_{2} \mathrm{e}$, while non-thinned plantation (20 ha) could be around $31.9 \mathrm{kt}-$ $\mathrm{CO}_{2}$ e. These stocks worth as much as USD 7,639 to 8,138 ha ${ }^{-1}$ each. Overall, Banacon Island's mangrove plantation is estimated to be around $64.5 \mathrm{ktC}$ or $236.6 \mathrm{ktCO}_{2} \mathrm{e}$, a blue carbon value that is worth conserving.

\section{Conclusion and Recommendation}

Three plantation types were assessed in terms of carbon stocks, namely: thinned mature stand, non-thinned mature stand; and young stand. In general, total carbon stock did not statistically differ between thinning and non-thinning of plantation stands which suggests that applying thinning management could be beneficial to provide local community with wood without compromising the plantations' capacity to sequester carbon. Self-thinning was observed at 1.1 to 1.3 tree $\mathrm{m}^{-2}$ as stands reach the age of 55 years old. This suggests the density level to be followed in thinning activities in order to generate a comparable amount of carbon stock to that of non-thinned or self-thinned treatment. The study suggests that thinning management is beneficial to complement carbon stock management. By estimate, an additional $580 \mathrm{tCO}_{2} \mathrm{e} \mathrm{ha}{ }^{-1}$ or USD 2,962 ha can be obtained from 20 to 55 years if thinning will follow the 1.1 to 1.3 tree $\mathrm{m}^{-2}$ design. Overall, the whole mangrove plantations of Banacon Island amass to $64.5 \mathrm{ktC}$ or 236.6 $\mathrm{ktCO}_{2} \mathrm{e}$, a value that is worth conserving to help mitigate climate change. Local community should therefore explore the possibility of developing a carbon offset project to realize both the ecological and economic benefits of their plantations. 
Acknowledgements. This study was made possible through the collaboration between the ASEAN-Korea Environmental Cooperation Project, University of the Philippines, Los Baños; Seoul National University, and the local community members of Banacon Island, Philippines.

\section{References}

Adornado, H. 2016. Mangrove and Beach Forest Development Project (MBFDP). - Paper presented at Carbon Sequestration of Mangroves during the Symposium on Mangroves for Climate Adaptive and Resilient Communities. Visayas, December 19-20, 2016, Cebu City, Philippines. [WWW document]. - URL http://climate.gov.ph [Accessed 20 February 2017].

Alongi, D. 2010. The Energetics of Mangrove Forest. Springer, USA. 216 pp.

Chan, H. 1996. Mangrove reforestation in Peninsular Malaysia: a case study of Matang. - Field, C. (ed.). Restoration of mangrove ecosystems. ISME/ ITTO, Okinawa, 64-75.

DENR. 2013. Forestry Statistics Department of Environment and Natural Resources. [WWW document]. - URL http//forestry.denr.gov.ph [Accessed 22 December 2017].

Deshar, R., Sharma, S., Hoque, A., Mouctara, K., Hagihara, A. 2012. Self-thinning of leaf, wood and aboveground in overcrowded mangrove Bruguiera gymnorrhiza stands in Okinawa Island, Japan. Procedia Environmental Sciences, 13, 982-993.

Donato, D., Kauffman, J., Kurnianto, S., Stidham, M., Murdiyarso, D. 2011. Mangroves among the most carbon-rich forests in the tropics. - Nature Geoscience, 4, 293-297.

Ecosystem Marketplace. 2017. Unlocking potential: State of the voluntary carbon markets 2017. Hamrick, K., Gallant, M. (eds.). Forest Trends' Ecosystem Marketplace. Washington, USA. 52 pp.

FAO. 2007. The world's mangrove: 1980-2005: A thematic study prepared in the network of the Global Forest Resource Assessment 2005. FAO Paper No. 153. Food and Agriculture Organization: Rome.

Garcia, K., Malabrigo, P., Gevaña, D. 2014. Philippines' mangrove ecosystem: Status, threats and conservation. - Hakeem et al. (eds.). Mangrove Ecosystem in Asia: Current Status, Challenges and Management Strategies. Springer, 81-94.

Gevana, D., Im, S. 2016. Allometric models for Rhizophora stylosa Griff. in dense monoculture plantation in the Philippines. - Malaysian Forester, 79(1\&2), 39-53.

Hairiah, K., Sitompul, S., Van Noorwijk, M., Palm, C. 2001. Methods for Sampling Carbon Stocks
Above and Below Ground. International Center for Research in Agroforestry, ASB Lecture Series Note 4B, Bogor, Indonesia. 23 pp.

IUCN. 2012. Blue Carbon Policy Framework: Based on the discussion of the International Blue Carbon Policy Working Group. - Herr, D., Pidgeon, E., Laffoley, D. (eds.). Gland, Switzerland: IUCN and Arlington, USA. 39 pp.

Kathiresan, K., Bingham, B. 2001. Biology of mangroves and mangrove ecosystems. - Advances in Marine Biology, 40, 81-251.

Lugo, A., Snedaker, S. 1974. The ecology of mangroves. Annual Review of Ecology and Systematics, 5, 39-65.

Matsui, N. 1998. Estimated stocks of organic carbon in mangrove roots and sediments in Hinchinbrook Channel, Australia. - Mangroves and Salt Marshes, 2, 199-204.

Nagasuka, T. 1979. Analysis of stand structure of mangroves. - Bulletin of Ryukyu University, 26, 413-519. (In Japanese with English summary).

Oliver, C., Larson, B. 1996. Forest Stand Dynamics. John Wiley and Sons, Inc., New York. 544 pp.

Pearson, T., Walker, S., Brown, S. 2005. Sourcebook for land use, land-use change and forestry projects. Winrock International, Arlington, VA, USA. 64 pp.

Pichon, M. 1977. Physiology, morphology and ecology of the Double Barrier reef of North Bohol (Philippines). Proceedings of the Thirds International Coral Reef Symposium, Miami, USA, 261-267.

Pulhin, J., Gevana, D., Pulhin, F. 2017. CommunityBased Mangrove Management in the Philippines: Experience and Challenges in the Context of Changing Climate. - DasGupta, R., Shaw, R. (eds.). Participatory Mangrove Management in a Changing Climate. Springer Nature, 247-262.

Putz, F., Chan, H. 1986. Tree growth, dynamics, and productivity in a mature mangrove forest in Malaysia. - Forest Ecology and Management, 17, 211-230.

Richards, D., Friess, D. 2016. Rates and drivers of mangrove deforestation in Southeast Asia, 20002012. - Proceedings of the National Academy of Sciences, 113(2), 1-2.

Saenger, P. 2002. Mangrove ecology, silviculture and conservation. Kluwe Academic Publishers. 360 pp.

Tamai, S., Nakasuga, T., Tabuchi, R., Ogino, K. 1986. Standing biomass of mangrove forest in Southern Thailand. - Journal of Japanese Forest Society, 68(9), 384-388.

Weller, D. 1987. A reevaluation of the $-3 / 2$ power rule of plant thinning. - Ecological Monograph, 57, 23-43.

Westoby, M. 1984. The self-thinning rule. - Advance Ecological Research, 14, 167-225.

Yoda, K., Kira, T., Ogawa, H., Hozumi, K. 1963. Selfthinning in overcrowded pure stands under cultivated and natural conditions. - Journal of Biology Osaka City University, 14, 107-129. 